\title{
Vzpomínka na Arnošta Lamprechta
}

V ř́jnu letošního roku uplynulo 100 let od narození bohemisty a slavisty, profesora na brněnské filozofické fakultě, výborného vysokoškolského pedagoga a skvělého člověka Arnošta Lamprechta.

Narodil se 19. října 1919 ve Štítině u Opavy. Po maturitě na reálném gymnáziu v Opavě (1938) byl přijat ke studiu na filozofické fakultě v Brně, obor čeština a němčina. Po absolvování dvou semestrů došlo $\mathrm{k}$ uzavření českých vysokých škol. Na fakultu se pak vrátil po válce, v roce 1945, dokončil ji v roce 1947 na oborech čeština a ruština. Jeho učiteli byli mimo jiné profesoři, ve svých oborech uznávané autority, paleoslovenista Josef Kurz, dialektolog Adolf Kellner, bohemista širokého záběru František Trávníček, slavista Bohuslav Havránek, indoevropeista a etymolog Václav Machek nebo literární historik a teoretik Frank Wollman. Po absolutoriu působil krátkou dobu jako středoškolský učitel (učil na reálném gymnáziu v Brně - Husovicích); v roce 1949 se na fakultu vrátil a setrval tu až do konce života (zemřel 2. května 1985). Působil tu nejprve jako odborný asistent, následně jako docent (od roku 1957), od roku 1962 jako profesor. Po doktorátu (PhDr., 1950) obhájil v roce 1956 jako jeden z prvních na brněnské filozofické fakultě vědeckou hodnost kandidáta věd (CSc.), v roce 1970 získal tehdy nejvyšší vědecký titul DrSc. Od roku 1963 až do své smrti vedl katedru českého jazyka, slovanské, indoevropské a obecné jazykovědy, když ve funkci vystřídal zesnulého Františka Trávníčka. Jeho organizační schopnosti se projevovaly v celé řadě dalších funkcí, které Lamprecht zastával, mimo jiné jako proděkan fakulty a prorektor brněnské univerzity. Od roku 1961 byl nadto externím vedoucím brněnského pracoviště Ústavu pro jazyk český ČSAV (dnes AV ČR).

Do širšího vědeckého povědomí vstoupil na počátku své vědecké kariéry jako dialektolog. Výsledky nářečního zkoumání rodného opavského kraje, které představil v několika statích, vyústily v monografie Stréedoopavské náreč̌i (1953) a Slovník středoopavského nářečí (1963), jež jsou jak metodologickým, tak materiálovým obohacením dialektologického výzkumu Opavska. Jeho badatelský zájem se však neomezoval jen na jazyk rodného kraje, ale brzy se rozšířil postupně i na ostatní české dialekty; jeho synchronně i diachronně fonologický a historickosrovnávací pohled na česká a moravská nářečí je dobře vidět v úvodní stati k čítance České náreční texty (1976), které redigoval.

Do jazykovědné bohemistiky zasahoval A. Lamprecht významně i mimo oblast vlastní dialektologie. Zajímala ho především historická fonologie češtiny. Synteticky ji vedle série odborných studií zpracoval v monografii Vývoj fonologického systému českého jazyka (1966, 
1968), v upravené podobě pak se stala součástí vysokoškolské učebnice Historický vývoj češtiny (1977), jejímž je Lamprecht autorem spolu s Jaroslavem Bauerem a Dušanem Šlosarem. Vliv jeho vysokoškolských učitelů, zejména Kellnera a Havránka, je zřejmý v Lamprechtově strukturním pojetí jazyka, jeho práce se vyznačují systematičností a soustavným hledáním a nacházením souvislostí a zároveň hlubokou znalostí materiálu. Vývoj fonologického systému přitom Lamprecht nepopisuje jako izolovaný autonomní proces, vždy uplatňuje hledisko srovnávací, češtinu vždy zasazuje do širšího kontextu ostatních slovanských jazyků a geneticky př́buzných jazyků neslovanských. Tento jeho široký pohled na jazykový vývoj je implikován v jeho pojednáních o fonologickém vývoji polštiny a celého západoslovanského areálu, o fonologickém vývoji pozdní praslovanštiny v areálu východoslovanském, o praslovanské morfologii, o chronologii fonologického vývoje praslovanštiny apod. Syntézou jeho celoživotního bádání o praslovanštině je monografie Praslovanština. Jejím jádrem je sice popis praslovanské fonologie, prostor je ovšem věnován i praslovanské morfologii; př́značné pro tuto publikaci (jako ostatně pro většinu Lamprechtových prací) je zasazení všech popisovaných jevů do širších slovanských souvislostí a přesahy do raných vývojových fází jednotlivých slovanských jazyků. Kniha vyšla až po jeho smrti v roce 1987.

Daleko za hranice slovanské jazykovědy mírily Lamprechtovy úvahy o vztahu indoevropských jazyků k jiným jazykovým rodinám, a to nejprve společně s Adolfem Erhartem, posléze s Mirkem Čejkou. Společně s M. Čejkou recenzovali etymologický slovník nostratických jazyků V. Illiče-Svityče $(1975,1977)$ a na základě teorie nostratických jazyků poté nově vykládali některé jevy indoevropské fonologie.

Vědecké zájmy A. Lamprechta byly ovšem mnohem širší, než bylo na tomto místě možné uvést. ${ }^{1} \mathrm{~V}$ každém př́padě lze však říci, že v české slovanské jazykovědě zanechal nesmazatelnou stopu a mnohé $\mathrm{z}$ jeho závěrů jsou aktuální dodnes.

Lamprecht byl také velmi oblíbený vysokoškolský učitel. Dovedl získat studenty svým temperamentním projevem, předkládajícím posluchačům složitou látku jasně a srozumitelně, často s vtipnými glosami. Byl znám jako př́sný, ale spravedlivý examinátor.

Arnošt Lamprecht byl uznávaný vědec, výborný řečník, který dovedl se zápalem sobě vlastním diskutovat o svém oboru, skvělý učitel, tolerantní a velkorysý kolega. Jeho mladší kolegové si vzali k srdci jeho krédo, které často opakoval: „Kdo chce dobře učit, musí dobře bádat.“

$1 \quad$ Kompletní bibliografický přehled v. MaLčík, Petr. 2016. Bibliographia Lamprechtii a Bibliographia Lamprechtiana. In: Dvǒ̌ÁK, Jan - MALČík, Petr, eds. Arnošt Lamprecht. Ke kořenům jazyků (= Studie osobností brněnské lingvistiky V). Brno: Host, 169-183 a 185-186.

Toto dílo lze užít v souladu s licenčními podmínkami Creative Commons BY-NC-ND 4.0 International (https://creativecommons.org/licenses/by-nc-nd/4.o/legalcode). Uvedené se nevztahuje na díla či prvky (např. obrazovou či fotografickou dokumentaci), které jsou v díle užity na základě smluvní licence nebo výjimky či omezení př́slušných práv. 


\section{Helena Karlíková}

Czech Language Institute of the CAS, v. v. i.

Veveří 97, 602 oo Brno

Czech Republic

helena.karlikova@ujc.cas.cz 
